\title{
Analysis and Construction of Elements of the Stage Performance Structure in a Kabuki-dance
}

\author{
Miku Kawai \\ Faculty of Software and Information Science, Iwate Prefectural University, \\ 152-52, Sugo, Takizawa, Iwate, 020-0693, Japan \\ Jumpei Ono \\ Faculty of Software and Information Technology, Aomori University, \\ 2-10-1, Seishincho, Edogawa, Tokyo, 134-0087, Japan \\ Takashi Ogata \\ Faculty of Software and Information Science, Iwate Prefectural University, \\ 152-52, Sugo, Takizawa, Iwate, 020-0693, Japan \\ g031p035@s.iwate-pu.ac.jp,j.ono@aomori-u.ac.jp \\ ogata@iwate-pu.ac.jp
}

\begin{abstract}
We conducted a detailed analysis of the stage performance structure of Kyōganoko Musume Dōjōji and reproduced it on the animation tool KOSERUBE with the music, lyrics, and images aligned. In this paper, 11 scenes of Kyōganoko Musume Dōjojji are organized. The actual flow is compared with the movement on the system. The goal of this paper is to understand the entire stage structure of Kyōganoko Musume Dōjōji in detail. In addition, this research aims to use the stage performance structural system for an integrated narrative system that the authors are developing. We believe that this system will be the basis for the construction of the Kabuki stage. Further, we want to apply it not only to Kabuki but also to other genres, such as computer games and commercials.
\end{abstract}

Keywords: Dōjōji, Stage Performance Structure, Narrative generation, Story

\section{Introduction}

Kabuki is a valuable cultural heritage, one of the elements of Japanese culture with a long history. Therefore, many studies have been conducted regarding the preservation and inheritance of such a heritage. In addition, Kabuki incorporates various performing arts from the genres of dance and classical performance, such as Noh and Kyogen. In recent years, we have worked actively to incorporate video technologies such as Computer Graphics. Additionally, in the vortex of
COVID-19, a new performance form called Zūmu Kabuki was created.

Zūmu Kabuki is a Kabuki stage in which each actor takes a video on the "Zoom" video calling app, and the videos are put together to form a single stage. This is also known as online Kabuki. In fact, from the end of June to the middle of July, the Zümu Kabuki Chüshingura was performed. In this way, Kabuki continues to develop by utilizing artificial intelligence and digital technology.

For example, last year, Hatsune Miku and Nakamura Shido co-starred at the Nico Nico Chōkaigi*, where a Kabuki called "Hana kurabe sen bon zakura" was

${ }^{*}$ A festival organized by DWANGO Co. Ltd. The festival has the content "Chō Kabuki”" (https://chokabuki.jp/2019minamiza/english/). (C) The 2021 International Conference on Artificial Life and Robotics (ICAROB2021), January 21 to 24, 2021 
performed. This is a stage that combines the world view of Hatsune Miku's representative song Senbonzakura with Kabuki (Minamiza, Kyoto, Aug. 2019). In addition, this year, the Ningyo Joruri Koimusume Tsumugi no Labyrince, using Hatsune Miku, is being held at the Tomioka Silk Mill (Tomioka, Gunma, Japan/Oct. 2020).

In Kabuki research, there have been many studies of the introduction of video technology. The heritage of Shosagoto (the body actions of actors) using motion capture has been analyzed in some studies. However, our research is different.

- Oda and Genda study the characteristic motion in Kabuki using a motion capture system. Omoto et al. create a model of Minamiza in Kyōto (Minamiza is a traditional Kabuki theatre). ${ }^{1}$

- A study (Kobayashi, 2017) compares Western dance in the ballet $L a$ sylphide, and the Japanese dance Kyōganoko Musume Dōjōji to investigate the creation of dances. This research focuses on "Furi $<$ swing $>$," mainly analyzing small movements such as walking and hand expressions. $^{2}$

- Using a commercially available robot (Desktop robot "Premade AI"), the stage of Ningyō Jōruri Hidakagawa Iriaizakura is reproduced remotely by the Tokyo University of Technology. ${ }^{3}$

We investigated and analyzed several of the elements that make up Kabuki and developed a system that simulates the interplay of stories. We use a system called KOSERUBE that partially reproduces the visual image of the stage performance structure of Kyoganoko Musume Dōjōji. In addition, we have conducted the following research so far.

- We have surveyed and analyzed Dōjōji stories and Kyōganoko Musume Dōjōji in Kabuki. ${ }^{4}$

- We have developed a system that simulates the stage performance structure of Kyōganoko Musume Dōjōji. ${ }^{5}$

- We have integrated narrative generation systems, including explanation generation, with the above simulation system. ${ }^{6}$

The current study focuses on the stage structure and aims to display the entire stage. Specifically, the purpose is to perform a detailed analysis of the stage structure and reproduce the stage performance structure. Therefore, this study does not necessarily analyze the body actions of the actors in detail. Kyōganoko Musume Dōjōji (The
Maiden at the Dōjōji Temple) is one work in many works based on the "legend of Dōjōji," told in narratives and picture scrolls. This is a latter-day description of the legend of Anchin and Kiyohime. The oldest legend of the Dōjōji work is Dainihonkoku Hokekyō Genki (Miraculous Tales of the Lotus Sutra from Japan). ${ }^{1}$ In the story, Anchin lies and is burned to death by Kiyohime; however, the power of the Lotus Sutra frees him from suffering.

We have conducted the following research so far.

1. As a study of Kabuki-dance: Analysis of Kyōganoko Musume Dōjōji. ${ }^{4}$

2. Analyze the stage performance structure of Kyōganoko Musume Dōjōji: We have developed a performance structure reproduction system. ${ }^{5}$

3. A combination of Unchiku, an explanation generation system, and an animation system.

4. Story generation related to love and sexuality using a Japanese classic tale.

We extracted the components of the story for use in our explanation generation system for a Kabuki-dance representation system.

$\operatorname{KOSERUBE}^{7,8}$ is an animation tool developed by the authors. We develop a system that reproduces the stage performance structure of Kyōganoko Musume Dōjōji with KOSERUBE. This research aims to automate the reproduction system of the stage performance structure and connect the system to story generation. ${ }^{9}$ To that end, this paper focuses on the dance scenes of Kyoganoko Musume Dōjōji and analyzes their stage elements. Kyōganoko Musume Dōjōji focuses on dance, but it involves scenes with narratives. However, in this study, we focus only on the dance scenes. Therefore, we have not analyzed all the scenes in Kyōganoko Musume Dōjōji.

\section{Analysis of Kȳ̄ganoko Musume Dōjōji}

Dōjōji is a temple of the Tendai sect in Hidakachō, Hidaka, Wakayama, Japan. This temple is the subject of the legend of Dōjōji, which has been recorded for over a thousand years. Although this legend has changed its shape over the long history, we think it is still known to many people. Of the versions of this legend, we focus on the Kabuki dance Kyōganoko Musume Dōjoji, which is considered the legend of modern Dōjōji. 


\subsection{Kyōganoko Musume Dōjōji}

Kyōganoko Musume Dōjōji is a representative work of Kabuki dance, known as a work played by representative female onnagata such as Nakamura Utaemon 6th and Tamasaburo Bando 5th. The ancient legend that led to the Kabuki dance Kyōganoko Musume Dōjōji was transmitted through Buddhist narratives, Noh, texts, picture scrolls, etc.

Kyōganoko Musume Dōjōji is a work that is a later development of the legend of Anchin and Kiyohime. Unlike the Kiyohime legend, which depicts a woman's obsession, she does not bring it to the fore in this version, using various kimonos and props to show her daughter in love, making it a completed work of Musume Dōjōji as a Kabuki dance. That is, it basically inherits the form of the Noh Dōjōji intact, but the legend of Dōjōji is not specifically shown in the verse. The theme is to show a changing dance.

The foundation of Dōjōji dance had already been laid in Noh's Dōjōji, and in Kyōganoko Musume Dōjōji it is transformed into a gorgeous and bright work, positioned as the completion of the modern transformation.

\subsection{The legend of Dōjōji}

The story of the legend of Dōjōji (also known as the legend of Anchin and Kiyohime) is Kiyohime, a woman living in Kumano who is betrayed by a Buddhist monk (Anchin). Her strong anger transforms her into a snake, and she burns the monk together with a bell in Dōjōji.

The legend of Dōjōji took a male point of view of a woman as evil, but since the Muromachi period, it has changed to the point of view of a woman's sadness.

\subsection{Analysis of Kyōganoko Musume Dōjōji}

Table 1 (following the references) shows the elements of Kyōganoko Musume Dōjōji and their implementation methods. The table includes the following five items for each scene:

(1) [Actual stages] Flow and characteristics of the dance on stage (the contents in brackets indicate scene characteristics);

(2) [Music] Music used in the system, based on the Kineie Shamisen score, and created with a free composition tool ("Wagaku Hitosuji," https://jonkara.net/soft/wagaku/). However, the system uses the actual music because there are no scores for "Michiyuki," "Ranbyōshi," and "Kaneiri." In other scenes, we only reproduced the music for the shamisen. Since the sound of the shamisen music feels higher than that on the actual stage, there is a lingering sense of discomfort compared with the actual music;

(3) [Lyrics] Excerpts from the beginning and end of the lyrics (only the "Ranbyōshi" is shown in full). The lyrics are romanized because they are written in old Japanese;

(4) [Images] Images of appearing characters, the main stage, and stage equipment. The props are listed in parentheses in the "Shirabyōshi Hanako";

(5) [Commands] The command is written in the code. Commands used in the system (input sentences instructing the reproduction system to create the character animation or the background).

\section{An Animation Mechanism based on the Structural Analysis of Scenes}

This section describes the generation of stage performance structures based on our analysis of Kyōganoko Musume Dōjōji. As we mentioned in Section 1 , our goal is to create a system that automatically generates a staging structure from certain inputs. This study is a preliminary phase. To study the system for automatic generation, we created an animation from the content shown in Table 1. First, this section describes an animation tool. Next, it shows the flow of creating an animation.

This study uses the user interface of KOSERUBE, which has two modules. The first module converts the generated stories into animation code specific to KOSERUBE, based on which the second module plays the animation.

In this study, we used the second module in the user interface and the date base of images. Moreover, additional music and images were prepared for the animation of Kyōganoko Musume Dōjōji. We manually created the animation code based on the analysis shown in Table 1. Next, we described how to create the animation code.

Figure 1 shows an example of an animation. The system reproduces a performance by combining a background and a character image on another image that imitates the play's stage. In addition, the music in Kyōganoko Musume Dōjōji, along with the text showing the story and lyrics of the music, are displayed at the bottom of the screen. Our research is not on computer graphics. Rather, the goal is to reproduce the elements 
that make up the entire stage. For this reason, the paper does not pursue reality and the animations that we created are below par.

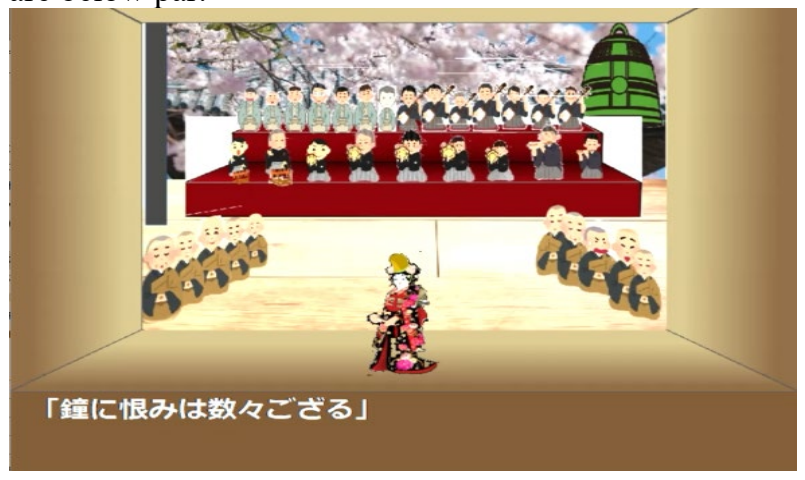

Fig. 1. Example of a visualized stage performance structure (Ranbyōshi).

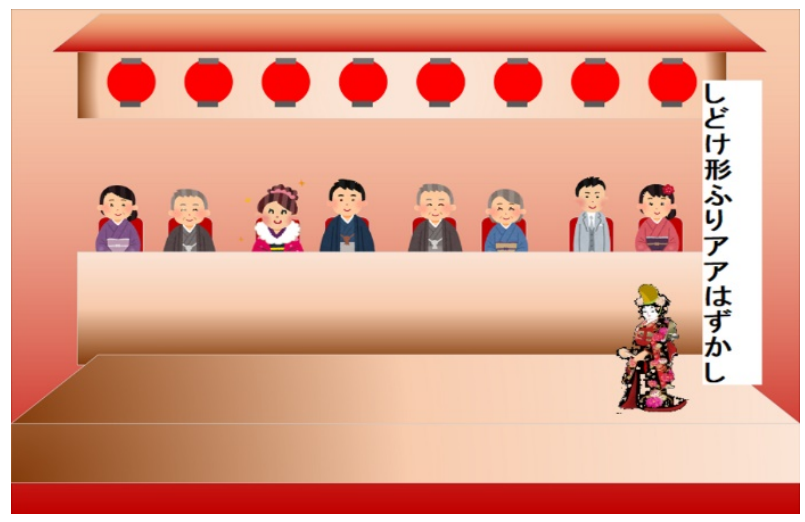

Fig. 2. Example of a visualized stage performance structure (Michiyuki).

The screen structure shown in Figures 1 and 2 uses background and human images stored in the image database of KOSERUBE. The screen consists of four layers: text, character, stage, and background. Here, the dancing figures are the characters, and the instrumentalists, monks, and bells are included in the background.

The system uses two kinds of music. First, the music of the actual Kyōganoko Musume Dōjōji and second, the electronic music created from a musical score. The musical score used was Nagauta Kyōganoko Musume Dōjoji: Shamisen Bunka-fu by Kineie. ${ }^{10}$ To create the music, we used a free composition tool called "Wagaku Hitosuji."

Next, we explain the details of the animation code. The animation code is a set of instructions to the user interface describing the combination of images and texts, detailed instructions for character animation, and the timing of playing music. The user interface section dynamically composes images, plays animations, and plays music based on the animation code.

Figure 3 is an example of character animation based on the animation code. The code represents an animation that makes the character jump in Figure 3. The "mov" command in Figure 3 is a primitive command for the character's image to move. We used multiple "moves" to represent the dances of the characters. For example, "mov, 11, v, $-50,-25$ " means, from left to right, "Command," "Character ID," "Direction of movement," "movement distance," and "movement speed." For example, "mov, 11, v, $-50,-25$ " moves "Shirabyōshi Hanako," with a character ID of 11. The movement distance is the -50 coordinate in the vertical direction relative to the current coordinates. The movement speed is -25 (every frame, the coordinates of the image move relative to the current coordinates by -25 pixels).

In Figure 3, the coordinates of the character image are moved up and down by multiple "moves." The "Code" in Figure 3 is a combination of "mov" for moving up and "mov" for moving down repeated three times, so that "Shirabyōshi Hanako" jumps off three times.

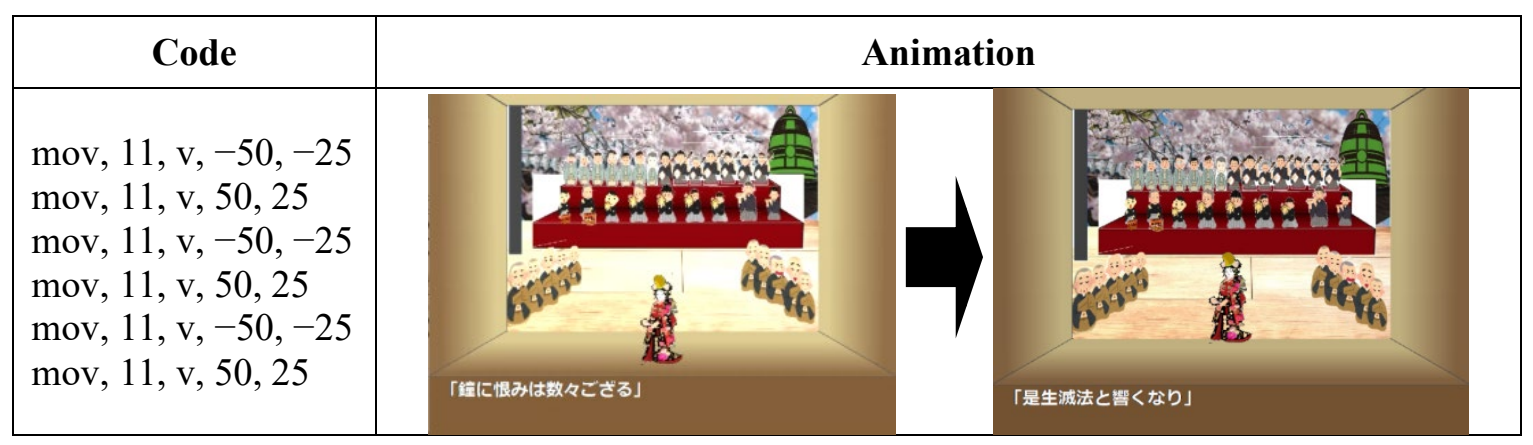

Fig. 3. An Example of Code for Visualizing Animation. 


\section{Discussion}

The future potential of the animation system used in this paper and how to use it are described below.

\subsection{Results}

We have analyzed the stage performance structure of Kyōganoko Musume Dōjōji and reproduced it with animation. In addition, the story of the legend of Dōjōji is organized and summarized in a table. We analyzed and organized the stage performance structure, including such elements as musical instruments and stage backgrounds, and created animation using KOSERUBE.

We also analyze the history and story of the legend of Dōjōji, focusing on the transformation of the story from the legend of Dōjōji to Kyōganoko Musume Dōjōji and the personality of the characters.

The future of the animation system and the prototype system using the story of Dōjōji are described below.

\subsection{Future Work: Combination of INGS and the Animation System}

The authors believe that this system will be the basis for creating the Kabuki stage. Figure 4 is an image of the system. The system outputs the stage performance structure by automatically generating the stage components based on the input story. The story entered in the system is prepared based on two methods, creation by hand and automatic generation. We have developed a system that automatically generates stories, the Integrated Narrative Generation System (INGS). We are studying a system that automatically generates the stage performance structure by combining the reproduction system with INGS. Finally, we want to apply the system not only to Kabuki but also to other genres, such as computer games and commercials.

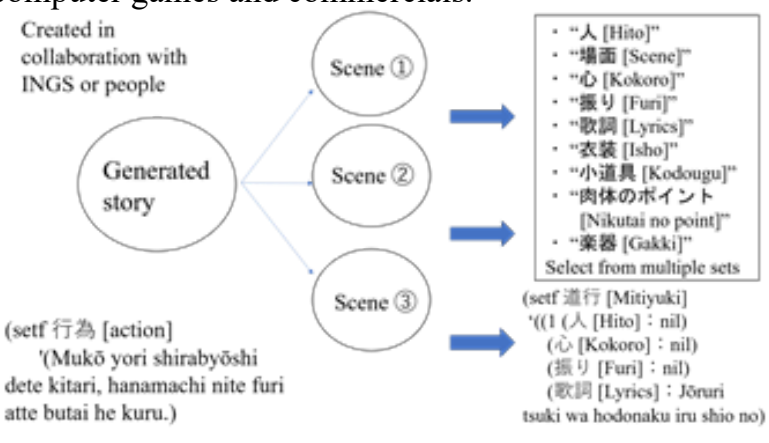

Fig. 4. Schematic of the stage structure reproduction system.

\subsection{Future Work: Parallel Generation System}

As mentioned in Section 2, the story of the legend of Dōjōji has changed during its long history. In addition, the character of Kiyohime has changed. Therefore, we reproduced the character of Kiyohime, which changes with the transformation of the story, with $2 \mathrm{D}$ and $3 \mathrm{D}$ animation.

In the legend of Dōjōji, the outline of the story is the same, but there are turning points in the story, such as the scene where Kiyohime turns into a snake and the way it ends. Scenes from the legend of Dōjōji, such as the turning point and turning into a snake, were reproduced with 2D animation and 3D animation. The goal of this system is for all scenes to be seamlessly represented using CG.

In particular, based on branches, many story scenes are generated in parallel, using the story units of the legend of Dōjōji. The system can also make one story line by selecting a possibility at each branch point.

Figure 4 shows an image of the prototype system, ${ }^{11}$ in which the $3 \mathrm{D}$ and $2 \mathrm{D}$ generation results for 16 scenes flow. In the first and last scenes, a part of the 2D animation system is played for about 30 seconds. In the 2D animation system, it represents a scene of Kyoganoko Musume Dōjōji.

The flow of the system starts from the first scene, after which the story is divided into multiple scenes. The scene expressed in 3D is in the Hokkekyo Genki ${ }^{12}$ and Konjaku Monogatari, ${ }^{13}$ containing the narratives of the legend of Dōjōji and the story of Dōjōji Engi. Then, returning to the first scene, the story ends.

In the scene where only the code is displayed, only the structure of the generated story is flowing because $3 \mathrm{D}$ has not been created yet.

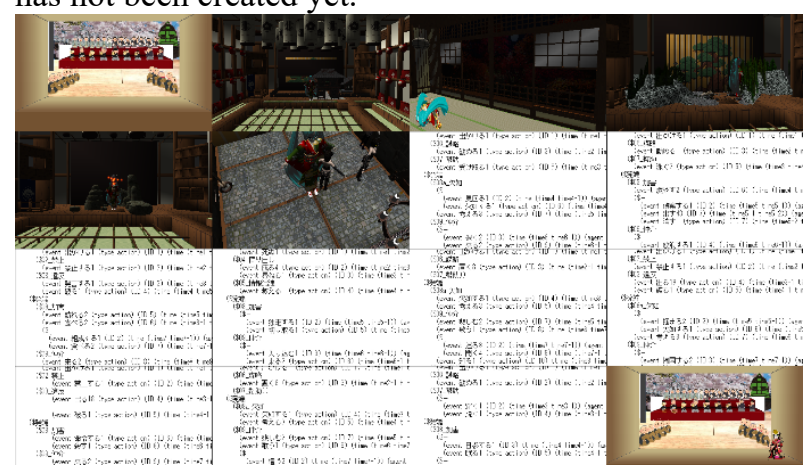

Fig. 5. Images of stage structure reproduction system. 


\section{Conclusion}

In this paper, 11 scenes of Kyōganoko Musume Dōjōji are organized to provide a detailed description of the entire stage structure of a Kabuki dance performance. In this study, we conduct a detailed analysis of the stage performance structure of Kyōganoko Musume Dōjōji and reproduce it with the animation tool KOSERUBE by aligning the music, lyrics, and images. The purpose of this analysis is to develop a system for reproduction of the stage performance structure of the dance. In the future, we will study its generation method based on the results of the analysis and develop an approach to build a more detailed reproduction system.

\section{Acknowledgements}

The research for this chapter was supported by the Japan Society for the Promotion of Science (JSPS KAKENHI), Grant No. 18K18509.

\section{References}

1. N. Omoto, K. Hasegawa, H. Motojima, S. Nagata and S. Tanaka, 3D model of Kyoto Minami-za theater and its application Prof, IPSJ SIG Computers and the Humanities, 2004, pp. 109-112.

2. Kobayashi. S, Approach to choreography "Kiyohime": a comparative study of Japanese traditional dance and western ballet for female (Doctoral dissertation), Osaka University of Arts, 2018.

3. R. Dong, Y. Chen, D. Cai, S. Nakagawa, T. Higaki and N. Asai, Robot motion design using bunraku emotional expressions: focusing on Jo-Ha-Kyū in sounds and movement, Advanced Robotics, 34(5), 2019, pp.299-312.

4. M. Kawai, J. Ono and T. Ogata, Analysis and Generation of the Narrative Elements in a "Dojoji" Story. Proceedings of the 3rd International Conference on Computational Intelligence and Intelligent Systems, 2020, pp.44-45.

5. M. Kawai, J. Ono and T. Ogata, Analyzing the Stage Performance Structure of a Kabuki-Dance, Kyōganoko Musume Dōjōji, Using an Animation System, In E. Ishita, N. L. S Pang \& L. Zhou (Eds.) Digital Libraries at Times of Massive Societal Transition (LNCS 12504), pp. 248254.Switzerland: Springer Nature, 2020.

6. J. Ono, M. Kawai and T. Ogata, Implementation of an Explanation Generation Mechanism Using Attribute Frames and a Noun Conceptual Dictionary. Proceedings of the 3rd International Conference on Computational Intelligence and Intelligent Systems, 2020, pp.48-50.

7. S. Imabuchi, J. Ono, J. Endo, Y. Kurisawa, R. Michimata, M. Kamada, T. Akimoto and T. Ogata, KOSERUBE: Folk Tales of Iwate: An Integrated Generation System of Language/Music/Image Based on Propp-based Story
Grammar Transactions, Proc. of the Japanese Society for Artificial Intelligence, 2012.

8. S. Imabuchi, T. Akimoto, J. Ono and T. Ogata KOSERUBE: An Application System with a Propp-based Story Grammar and Other Narrative Generation Techniques, Proc. of the Symposium on Cryptography and Information Security, 2012.

9. S. Imabuchi, T. Akimoto, J. Ono and T. Ogata, KOSERUBE: An Application System with a Propp-based Story Grammar and Other Narrative Generation Techniques, Proc. of the Symposium on Cryptography and Information Security, 2012.

10. Kineie Yashichi IV, Nagauta Kyōganoko Musume Dōjōji: Shamisen Bunka Fu Hōgakusha Beppu, Oita, Japan, 1952, Feb. 2018, pp. 174-177.

11. M. Kawai, J. Ono and T. Ogata, Dual Story Generation Based on Love and Extreme Emotions, Proceedings of 2020 The 3rd International Conference on Computational Intelligence and Intelligent Systems, 2020.

12. M. Inoue and S. Ōsone (Collation Eds.), Dainipponkoku Hokkekyō Genki, Ōjōden Hokkegenki, Iwanami Shoten, Tokyo, 1974, pp. 43-219.

13. K. Mabuchi, F. Kunisaki and Toru Konno, Konjalkumonogatarisyu vol.1., Shogakukan, 1919. 
Table 1. Stage performance structure.

\begin{tabular}{|c|c|c|c|c|c|}
\hline Scene name & Actual stages & Music & Lyrics & Images & Commands \\
\hline \multirow[t]{2}{*}{ Michiyuki } & $\begin{array}{l}\text { Shoke walks from } \\
\text { Hanamichi. } \\
\text { Talk about Kane's } \\
\text { memorial service on } \\
\text { stage. A stage device } \\
\text { imitating the door to the } \\
\text { temple will be prepared } \\
\text { on the stage. } \\
\text { The narrator and the } \\
\text { shamisen player come } \\
\text { out and sit on a long } \\
\text { table. }\end{array}$ & $\begin{array}{l}\text { Existing } \\
\text { music } \\
\text { (Jōruri) }\end{array}$ & $\begin{array}{l}\text { "Tsuki ha } \\
\text { hodonaku } \\
\text { hairu Shiono } \\
\text { (omission) } \\
\text { Hirari bōshi } \\
\text { no fuwafuwa } \\
\text { to" }\end{array}$ & $\begin{array}{l}\text { - Characters: Shoke (12 people) } \\
\text { - Katarite } \\
\text { - Musicians: Shamisen [Japanese guitar] } \\
\text { - Place on stage: Main stage, Hanamichi } \\
\text { - Stage equipment: Dōjōji, Kane, Cherry } \\
\text { blossoms }\end{array}$ & \multirow[t]{2}{*}{$\begin{array}{l}\text { Not } \\
\text { reproduced at } \\
\text { the time of } \\
\text { this paper. }\end{array}$} \\
\hline & $\begin{array}{l}\text { Shirabyōshi Hanako } \\
\text { comes out of Hanamichi } \\
\text { with a fan. } \\
\text { Perform a dance along } \\
\text { with Shirabyōshi. } \\
\text { After the dance, head to } \\
\text { the stage. }\end{array}$ & $\begin{array}{l}\text { Existing } \\
\text { music } \\
\text { (Noh) }\end{array}$ & $\begin{array}{l}\text { "Shidokenari } \\
\text { furi ā } \\
\text { hazukashi ya } \\
\text { (omission) } \\
\text { Dōjōji ni koso } \\
\text { tsukinikere" }\end{array}$ & $\begin{array}{l}\text { - Characters: Shirabyoushi Hanako, } \\
\text { Shoke (12 people) } \\
\text { - Katarite } \\
\text { - Musicians: Shamisen [Japanese guitar] } \\
\text { - Place on stage: Main stage, Hanamichi } \\
\text { - Stage equipment: Dōjōji, Kane, Cherry } \\
\text { blossoms }\end{array}$ & \\
\hline Ranbyōshi & $\begin{array}{l}\text { Put on the Eboshi given } \\
\text { by Shoke. Move from } \\
\text { the stage to Hanamichi } \\
\text { according to Noh. Show } \\
\text { off the dance. After that, } \\
\text { return to the stage from } \\
\text { Hanamichi. Perform a } \\
\text { dance at the center of the } \\
\text { stage (Mai has many } \\
\text { small movements of } \\
\text { wrists, feet, and props.) }\end{array}$ & $\begin{array}{l}\text { Existing } \\
\text { music } \\
\text { (Noh) }\end{array}$ & $\begin{array}{l}\text { "Hana no } \\
\text { hoka ni ha } \\
\text { matsu bakari } \\
\text { hana no hoka } \\
\text { ni ha matsu } \\
\text { bakari } \\
\text { kuresomete } \\
\text { kane ya } \\
\text { hibikuran" }\end{array}$ & $\begin{array}{l}\text { - Characters: Shirabyōshi Hanako, Shoke } \\
\text { (12 people) } \\
\text { - Katarite } \\
\text { - Musicians: Hyōshiita } \\
\text { - Place on stage: Main stage, Hanamichi } \\
\text { - Stage equipment: Dōjōji, Kane, Cherry } \\
\text { blossoms }\end{array}$ & $\begin{array}{l}\text { "Hana" } \\
\text { command } \\
\text { makes it look } \\
\text { like he is } \\
\text { going back } \\
\text { and forth } \\
\text { between the } \\
\text { stage and } \\
\text { Hanamichi. }\end{array}$ \\
\hline Chūkeinomai & $\begin{array}{l}\text { Continuing from } \\
\text { Ranbyōshi, perform a } \\
\text { dance at the center of the } \\
\text { stage in tune with } \\
\text { Kanedukushi. }\end{array}$ & $\begin{array}{l}\text { Create } \\
\text { from } \\
\text { score } \\
\text { (Nagauta } \\
\text { ) }\end{array}$ & $\begin{array}{l}\text { "Kane ni } \\
\text { urami ha } \\
\text { kazukazugoza } \\
\text { ru (omission) } \\
\text { Shinnyo no } \\
\text { tsuki wo } \\
\text { nagameakasa } \\
\text { n" }\end{array}$ & $\begin{array}{l}\text { - Characters: Shirabyōshi Hanako (Have } \\
\text { Chūkei), Shoke (12 } \\
\text { people) } \\
\text { - Katarite } \\
\text { - Musicians: Shamisen [Japanese guitar], } \\
\text { Taiko [Drum] } \\
\text { - Place on stage: Main stage } \\
\text { - Stage equipment: Dōjōji, Kane, Cherry } \\
\text { blossoms }\end{array}$ & $\begin{array}{l}\text { Not much } \\
\text { movement, } \\
\text { many small } \\
\text { dances. }\end{array}$ \\
\hline Teodori & $\begin{array}{l}\text { Reappear on the stage } \\
\text { without props. Perform } \\
\text { at the center of the stage } \\
\text { along with Hauta (Shōfu } \\
\text { no Erothishizumu). }\end{array}$ & $\begin{array}{l}\text { Create } \\
\text { from } \\
\text { score } \\
\text { (Nagauta } \\
\text { ) }\end{array}$ & $\begin{array}{l}\text { "Iwazu } \\
\text { kataranu } \\
\text { waga kokoro } \\
\text { (omission) } \\
\text { Miyakosodac } \\
\text { hi wa } \\
\text { hasuppana } \\
\text { mono ja e" }\end{array}$ & $\begin{array}{l}\text { - Characters: Shirabyōshi Hanako, Shoke } \\
\text { (12 people) } \\
\text { - Katarite } \\
\text { - Musicians: Shamisen [Japanese guitar], } \\
\text { Taiko [Drum], Kodutumi, } \\
\text { Fue [Flute] } \\
\text { - Place on stage: Main stage } \\
\text { - Stage equipment: Dōjōji, Kane, Cherry } \\
\text { blossoms }\end{array}$ & $\begin{array}{l}\text { Not much } \\
\text { movement, } \\
\text { many small } \\
\text { dances. }\end{array}$ \\
\hline Mariuta & $\begin{array}{l}\text { Perform dance at the } \\
\text { center of stage in } \\
\text { accordance with Rō- } \\
\text { dzukushi (Yūjo) } \\
\text { (choreography like } \\
\text { playing with Kakū no } \\
\text { Mari). }\end{array}$ & $\begin{array}{l}\text { Create } \\
\text { from } \\
\text { score } \\
\text { (Nagauta } \\
\text { ) }\end{array}$ & $\begin{array}{l}\text { "Koi no wake } \\
\text { sato } \\
\text { (omission) } \\
\text { Omoi } \\
\text { sometaga en } \\
\text { ja e" }\end{array}$ & $\begin{array}{l}\text { - Characters: Shirabyōshi Hanako, Shoke } \\
\text { (12 people) } \\
\text { - Katarite } \\
\text { - Musicians: Shamisen [Japanese guitar], } \\
\text { Taiko [Drum], Kodutumi, } \\
\text { Fue [Flute], Kane } \\
\text { - Place on stage: Main stage } \\
\text { - Stage equipment: Dōjōji, Kane, Cherry } \\
\text { blossoms }\end{array}$ & $\begin{array}{l}\text { By repeating } \\
\text { the vertical } \\
\text { movement, it } \\
\text { is possible to } \\
\text { express that a } \\
\text { ball is } \\
\text { attached. }\end{array}$ \\
\hline \multirow[t]{2}{*}{$\begin{array}{l}\text { Hanakasaodo } \\
\text { ri }\end{array}$} & $\begin{array}{l}\text { Put Hanakasa on the } \\
\text { head and hands at the } \\
\text { center of the stage. } \\
\text { Perform the dance } \\
\text { according to } \\
\text { Wakitebushi. } \\
\text { Shirabyōshi Hanako and } \\
\text { disappears from the } \\
\text { stage. }\end{array}$ & \multirow[t]{2}{*}{$\begin{array}{l}\text { Create } \\
\text { from } \\
\text { score } \\
\text { (Nagauta } \\
\text { ) }\end{array}$} & \multirow[t]{2}{*}{$\begin{array}{l}\text { "Ume to-san- } \\
\text { san sakura wa } \\
\text { (omission) } \\
\text { Kawairashi-sa } \\
\text { no hanako" }\end{array}$} & $\begin{array}{l}\text { - Characters: Shirabyōshi Hanako } \\
\text { (Hanakasa), Shoke (12 } \\
\text { people) } \\
\text { - Katarite } \\
\text { - Musicians: Shamisen [Japanese guitar], } \\
\text { Taiko [Drum], Fue [Flute], } \\
\text { Kane } \\
\text { - Place on stage: Main stage } \\
\text { - Stage equipment: Dōjōji, Kane, Cherry } \\
\text { blossoms }\end{array}$ & \multirow[t]{2}{*}{$\begin{array}{l}\text { The character } \\
\text { does not } \\
\text { move much } \\
\text { because the } \\
\text { movement of } \\
\text { Hanakasa is } \\
\text { the main } \\
\text { movement. }\end{array}$} \\
\hline & $\begin{array}{l}\text { All Shoke line up on } \\
\text { stage with Hanakasa. } \\
\text { Show off the dance. }\end{array}$ & & & $\begin{array}{l}\text { - Characters: Shoke (12 people) } \\
\text { - Katarite } \\
\text { - Musicians: Shamisen [Japanese guitar], } \\
\text { Taiko [Drum], Fue [Flute], } \\
\text { Kane } \\
\text { - Place on stage: Main stage }\end{array}$ & \\
\hline
\end{tabular}

(C) The 2021 International Conference on Artificial Life and Robotics (ICAROB2021), January 21 to 24, 2021 


\begin{tabular}{|c|c|c|c|c|c|}
\hline Scene name & Actual stages & Music & Lyrics & Images & Commands \\
\hline & & & & $\begin{array}{l}\text { - Stage equipment: Dōjōji, Kane, Cherry } \\
\text { blossoms }\end{array}$ & \\
\hline Kudoki & $\begin{array}{l}\text { Appear with Tenugui at } \\
\text { the center of the stage. } \\
\text { Show off Mai along with } \\
\text { Koi to Shitto no Kouta. }\end{array}$ & $\begin{array}{l}\text { Create } \\
\text { from } \\
\text { score } \\
\text { (Nagauta } \\
\text { ) }\end{array}$ & $\begin{array}{l}\text { "Koi no } \\
\text { tenarai tsui } \\
\text { minaraite } \\
\text { (omission) } \\
\text { Sawaraba } \\
\text { ochin } \\
\text { fuzeinari" }\end{array}$ & $\begin{array}{l}\text { - Characters: Shirabyōshi Hanako } \\
\text { (Tenugui), Shoke (12 } \\
\text { people) } \\
\text { - Katarite } \\
\text { - Musicians: Shamisen [Japanese guitar], } \\
\text { Taiko [Drum], Kodutumi } \\
\text { - Place on stage: Main stage } \\
\text { - Stage equipment: Dōjōji, Kane, Cherry } \\
\text { blossoms }\end{array}$ & $\begin{array}{l}\text { Tenugui is } \\
\text { wrapped } \\
\text { around the } \\
\text { body or held } \\
\text { in the mouth. } \\
\text { In this way, } \\
\text { the character } \\
\text { is not moving } \\
\text { because the } \\
\text { focus is on } \\
\text { using props. }\end{array}$ \\
\hline Yamadukushi & $\begin{array}{l}\text { Appear with Kakko } \\
\text { close to the center of the } \\
\text { stage. Show Mai while } \\
\text { hitting Kakko according } \\
\text { to Yama-Zukushi. }\end{array}$ & $\begin{array}{l}\text { Create } \\
\text { from } \\
\text { score } \\
\text { (Nagauta } \\
\text { ) }\end{array}$ & $\begin{array}{l}\text { "Omoshiro } \\
\text { shikinonagam } \\
\text { eya } \\
\text { (omission) } \\
\text { Tsuki no } \\
\text { kaobase } \\
\text { Mikasayama" }\end{array}$ & $\begin{array}{l}\text { - Characters: Shirabyōshi Hanako } \\
\text { (Kakko), Shoke (12 } \\
\text { people) } \\
\text { - Katarite } \\
\text { - Musicians: Shamisen [Japanese guitar], } \\
\text { Taiko [Drum], Kodutumi, } \\
\text { Hyōshiita, Kakko } \\
\text { - Place on stage: Main stage } \\
\text { - Stage equipment: Dōjōji, Kane, Cherry } \\
\text { blossoms }\end{array}$ & $\begin{array}{l}\text { Rotational } \\
\text { movements } \\
\text { using Kakko. }\end{array}$ \\
\hline Teodori & $\begin{array}{l}\text { Reappear on the stage } \\
\text { with nothing. Perform at } \\
\text { the center of the stage } \\
\text { along with Hauta (Shōfu } \\
\text { no Erotishizumu). }\end{array}$ & $\begin{array}{l}\text { Create } \\
\text { from } \\
\text { score } \\
\text { (Nagauta } \\
\text { ) }\end{array}$ & $\begin{array}{l}\text { "Tada tanome } \\
\text { (omission) } \\
\text { Niku terashi } \\
\text { hodo } \\
\text { itoshirashi" }\end{array}$ & $\begin{array}{l}\text { - Characters: Shirabyōshi Hanako, Shoke } \\
\text { (12 people) } \\
\text { - Katarite Musicians: Shamisen [Japanese guitar], } \\
\text { Taiko [Drum], Fue [Flute] } \\
\text { - Place on stage: Main stage } \\
\text { - Stage equipment: Dōjōji, Kane, Cherry } \\
\text { blossoms }\end{array}$ & $\begin{array}{l}\text { Not much } \\
\text { movement, } \\
\text { many small } \\
\text { dances. }\end{array}$ \\
\hline Shuzudaiko & $\begin{array}{l}\text { Around the center of the } \\
\text { stage, hit Suzudaiko and } \\
\text { perform a dance along } \\
\text { with taueuta (Saotome } \\
\text { odori). }\end{array}$ & $\begin{array}{l}\text { Create } \\
\text { from } \\
\text { score } \\
\text { (Nagauta } \\
\text { ) }\end{array}$ & $\begin{array}{l}\text { "Hana ni } \\
\text { kokoro o } \\
\text { fukamigusa } \\
\text { (omission) } \\
\text { Hiki ka } \\
\text { dezuite zo use } \\
\text { ni keru" }\end{array}$ & $\begin{array}{l}\text { - Characters: Shirabyōshi Hanako } \\
\text { (Suzudaiko), Shoke (12 } \\
\text { people) } \\
\text { - Katarite } \\
\text { - Musicians: Shamisen [Japanese guitar], } \\
\text { Taiko [Drum], Kodutumi, } \\
\text { Hyōshiita, Suzudaiko } \\
\text { - Place on stage: Main stage } \\
\text { - Stage equipment: Dōjōji, Kane, Cherry } \\
\text { blossoms }\end{array}$ & $\begin{array}{l}\text { Suzudaiko is } \\
\text { difficult to } \\
\text { reproduce } \\
\text { because it } \\
\text { turns its wrist } \\
\text { and rings. }\end{array}$ \\
\hline Kaneiri & $\begin{array}{l}\text { Shirabyōshi Hanako } \\
\text { defeats all Shoke. Kane } \\
\text { comes down on stage. } \\
\text { Shirabyōshi Hanako } \\
\text { climbs on Kane and } \\
\text { gazes around her like a } \\
\text { snake. }\end{array}$ & & & $\begin{array}{l}\text { - Characters: Shirabyōshi Hanako, Shoke } \\
\text { (12 people) } \\
\text { - Katarite Musicians: Shamisen [Japanese guitar], } \\
\text { Suzudaiko } \\
\text { - Place on stage: Main stage } \\
\text { - Stage equipment: Dōjōji, Kane, Cherry } \\
\text { blossoms }\end{array}$ & $\begin{array}{l}\text { Not } \\
\text { implemented } \\
\text { because it is } \\
\text { not a dance } \\
\text { part. }\end{array}$ \\
\hline
\end{tabular}

